\title{
Some Soil Age-Range Vegetation Relationships ${ }^{1}$
}

\section{E. M. WHITE}

Professor of Plant Science (Soils), South Dakota State University, Brookings.

\section{Highlight}

Soil texture and development determine the kinds of range plants that grow in west central South Dakota. Bluestems, sideoats grama, and prairie sandreed are important species on very weakly developed soils but are less important on more strongly developed soils than cool-season mid- and tall-grasses. Western wheatgrass, green needlegrass, and buffalograss are important on well developed soils except those that are very coarse textured where needleandthread is important. Soil structure and fertility changes probably are the important factors affecting vegetation as a soil develops.

Some environmental factors affecting vegetation were discussed by Weaver and Darland (1949), Weaver and Albertson (1956), and Weaver (1958) for the plains species. Albertson (1937) reported certain kinds of mixed prairie were associated with certain kinds of soils in western Kansas. In North Dakota, Hanson and Whitman (1938) described the gencral kind of soil for nine vegetation types and Dix

\footnotetext{
${ }^{1}$ South Dakota Agricultural Experiment Station Journal Series 882. Received October 5, 1970.
}

(1958) related the vegetation to slope gradient and slope aspect. Some soil-plant relationships were described for southwestern South Dakota by Tolstead (1941) and by Larson and Whitman (1941). Mixed prairie species that are found on soils in different stages of development have not been discussed in detail. The need for soil-vegctation interpretation studies in range management has been discussed by Klemmedson (1970).

The effect soil age and texture has on plant composition on welldrained slopes has been studied for
10 years (1958 to 1968 ) as part of the soil survey of Mellette County, South Dakota. This county (Fig. 1) has an area of about 834,000 acres and is about 30 miles north of the Nebraska line and 100 miles east of the Black Hills. The annual precipitation ranges from about 18 inches in the $\mathrm{SE}$ corner to 16 inches in the NW corner of the county (Hodges, 1960). Average July and January temperatures are about 77 $\mathrm{F}$ and $21 \mathrm{~F}$, respectively. Soils are derived from Cretaceous-Age Pierre shale, from Tertiary-Age shales, siltstones, and sandstone, and from Quaternary-Age alluvial and eolian sediments. The area has had several erosion cycles which have removed some of the older soils from the landscape. Soils derived from each parent material range from weakly developed to well developed and the vegetation growing on them forms a successional sequence.

Most of Mellette County lies in the broad Wheatgrass-Needlegrass (Agropyron-Stipa) vegetation type of Küchler (1964) except for small areas of the Wheatgrass-GramaBuffalograss (Agropyron-BoutelouaBuchloe) and Northern Floodplain 


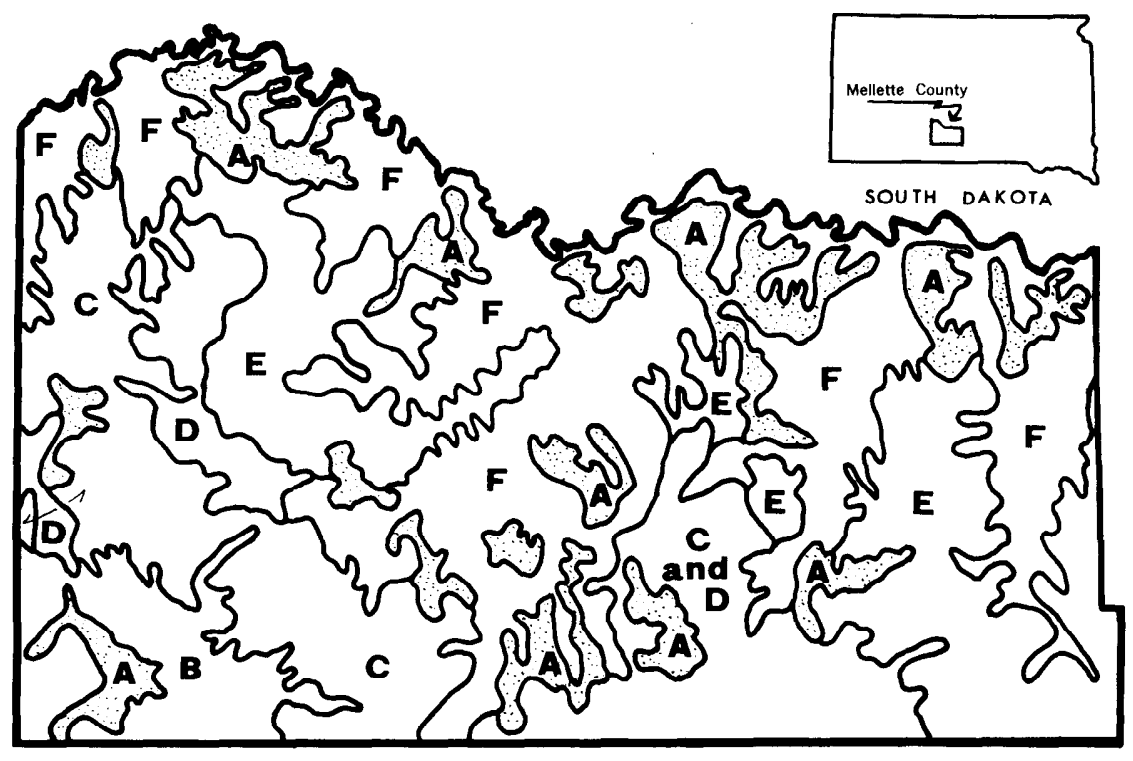

Fic. 1. Generalized soil-vegetation map of Mellette County: (A) (Stippled pattern) Loamy or sandy soils derived from eolian and stream terrace deposits with the needleandthread-blue grama-western wheatgrass or the bluestem sp.-sideoats grama vegetation types; (B) silty soils derived from Tertiary siltstone with needleandthreadblue grama-western wheatgrass vegetation type; (C) Badlands with barren areas interspersed with areas of vegetation similar to B, D, and F; (C) and (D). Complex of many small areas of C and D; (D) Silty clay loam and clay soils from Tertiary shales with western wheatgrass-green needlegrass (or needleandthread on silty clay loams)-blue grama vegetation types; (E) Clay soils derived from Cretaceous Pierre shale with western wheatgrass-green needlegrass-blue grama vegetation types; (F) Thin clay soils derived from Cretaceous Pierre shale with little bluestem-big bluestemsideoats grama vegetation types.

Forest (Populus-Salix-Ulmus) vegetation types. The generalized soilvegetation map of Mellette County (Fig. 1) is more detailed than Küchler's map. In addition, ponderosa pine (Pinus ponderosa) occurs in some Badlands and burr oak (Quercus macrocarpa) grows in some upland drainageways and low stream terraces or floodplains.

\section{Materials and Methods}

Vegetation, by species (Fernald, 1950; Hitchcock and Chase, 1950; Kelsey and Dayton, 1942), is reported on a relative weight basis by visual estimation. These composition estimates are similar to those reported by Lewis et al. (1963, Appendix Table 3) that are used for range management. In the process of soil mapping, each soil profile was related to the plant composition at that location. Thus, thousands of individual observations made over the 10 -year period have been summarized graphically in this paper.
Tentative soil series for the diagrams in Figure 2 are from left to right with increasing soil development: (1) for sands-Valentine, Dunday, Mander, Anselmo, and Tuthill; (2) for siltstone-Epping, Keota, and Huggins; (3) for silty clay loam shale-Imlay and Norrest; (4) for Pierre shale-Samsil, Lakoma, and Opal; (5) for finetextured shale-unnamed series and Larvie. Parent materials with only 1 or 2 series have other soils, which will be named in the future.

Changes in soil profiles with increasing age in southwestern South Dakota are similar to those commonly recognized in more humid areas. However, the weathering of the parent material is slower so the soil morphological propertics arc slightly different and will be described briefly. Very young soils in Mellette County inherit properties from the parent material which may be fractured hard rock, soft rock, or sediment deposited by wind or water. As rock fragments weather the soil initially becomes finer textured and later clay and silt are weathered or transported from the $A$ horizon and added to the $B$ horizon. Thus the A horizon may be coarse textured initially, then fine textured when the rock fragments are weathered, and coarser textured again as clay moves from $\mathrm{A}$ into the $B$ horizon. The development of soil structure (White, 1967) has been discussed as a factor causing Dense Clay and Clayey Range soils (White and Lewis, 1969).

\section{Observations and Discussion}

Grass Species in Relationship to Soil Development and Texture

Changes in plant composition associated with increasing soil age and development (Fig. 2) are quite similar irrespective of parent material. Warm-season tall bunch-grasses probably are dominant on very weakly developed soils because insufficient nitrogen and phosporus is available so the cool-season grasses can grow and use plant-available water before the warm-season bunchgrasses initiate rapid growth (White, 1961). Weakly developed soils on steep slopes with much water runoff and on low terraces with little water runoff have tall warm-season grasses ( if not overgrazed) so water runoff does not seem to be a factor. In more humid regions these warm-season grasses probably grow on well-developed soils because precipitation is sufficient to replenish soil moisture after the cool-scason grasscs have matured. A few moderately moist areas in Mellette County, either subirrigated or with considerable run-in water, have the tall warmseason grasses if the dark-colored soil is moderately fine to coarse textured. If the moist-area soil is fine textured, western wheatgrass usually (Agropyron smithii) is dominant although green needlegrass (Stipa viridula), big bluestem, sideoats grama (Bouteloua curtipendula), and switchgrass (Panicum virgatum) may be abundant. The relationship of grass species to soils will be discussed in the general 

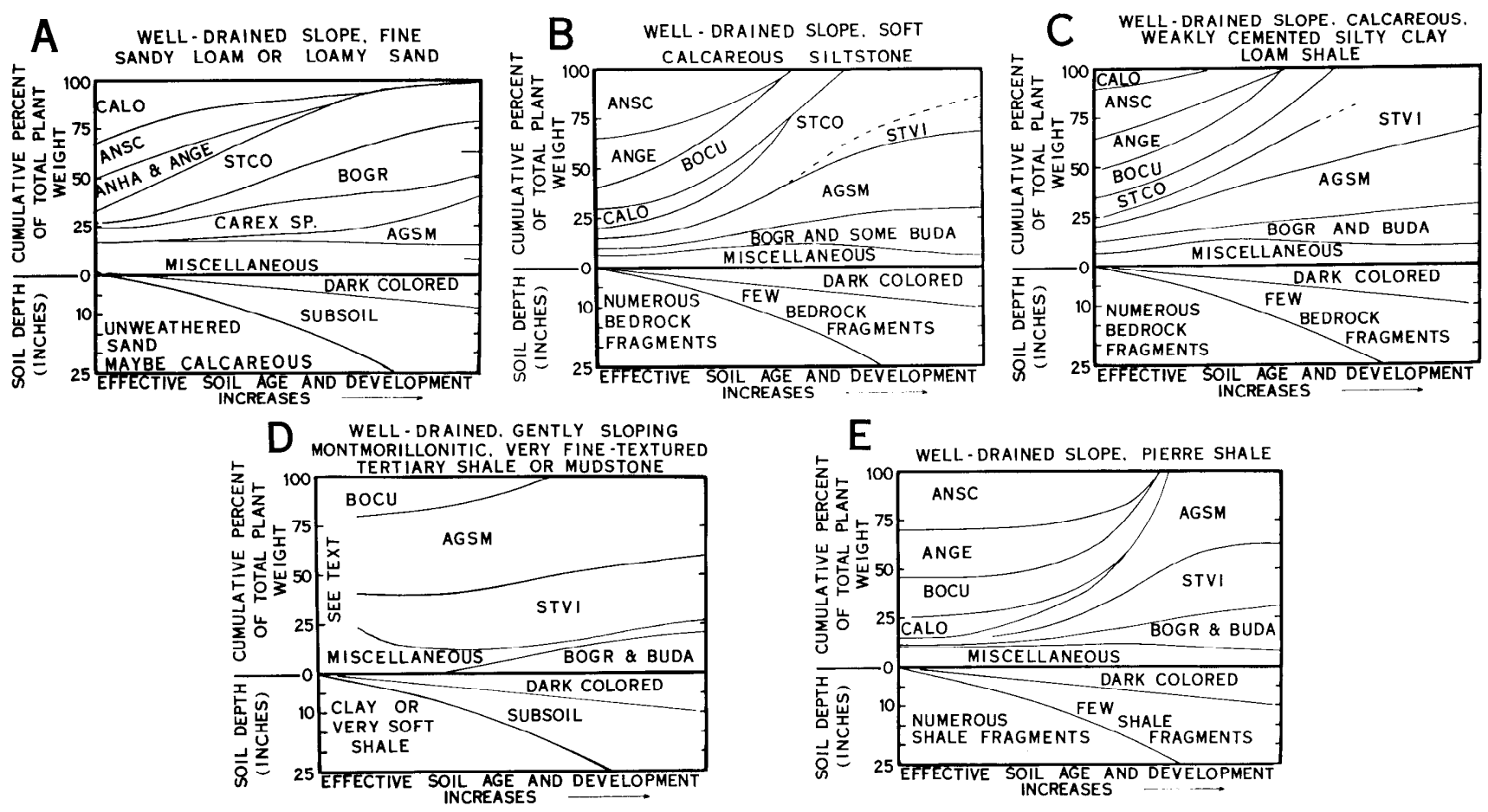

Fic. 2. Relationship of the abundance of common mixed prairie grasses to the development of soils derived from different parent materials on well-drained slopes that do not collect run-in water. AGSM, Agropyron smithii; ANGE, Andropogon gerardi; ANHA, Andropogon hallii; ANSC, Andropogon scoparius; BOCU, Bouteloua curtipendula; BOGR, Bouteloua gracilis; BUDA, Buchloe dactyloides; CALO, Calamovilfa longifolia; SPCR, Sporobolus cryptandrus; STUCO, Stipa comata; and STVI, Stipa viridula.

order form weakly developed to more strongly developed soils.

Prairie sandreed (Calamovilfa longifolia) is most abundant on the weakly developed soils, particularly those with loose sandy and silty profiles in Mellette County (Fig. 2-A and B, Fig. 3). Other weakly developed soils with considerable prairie sandreed have coarse-textured profiles formed from sand- or pebble-size fragments of the bedrock. A rhizomatous plant such as prairie sandreed or sand bluestem (Andropogon hallii), may be adapted to weakly developed sandy soils mainly because one seedling can spread over an area where seedlings of other species cannot grow. The relationship of sand bluestem to big bluestem supports this hypothesis.

Sand bluestem and big bluestem usually grows on weakly developed soils with respectively, sandy and clayey textures. The two species interbreed because plants of intermediate phenotype occur at the border of weakly developed sandy and clayey soils. However, in very small sandy areas, this interbreeding is either ( 1 ) very limited so sand bluestem can be preserved as a distinct species, or (2) a single sand bluestem plant spreads and maintains itself for a very long time by producing new plants vegetatively from long rhizomes. Sand bluestem must be more adapted to weakly developed sandy soils than big bluestem because of the long rhizomes or some related root characteristics. On gravelly soils, big bluestem seems to be adapted although the gravel deposits are thin in Mellette County so the finer underlying material may be the controlling factor.

Little bluestem (Andropogon scoparius) grows with big bluestem or sand bluestem on weakly developed soils. Little and big bluestems will grow on very fine textured soils if they contain shale fragments but not if the shale fragments are not present (Fig. 2, D in comparison to E). Little bluestem may grow on well-developed soils which have been disturbed by burrowing animals or by man. Competition from other species has been eliminated in these disturbed soils so they are similar to the weakly developed soils where competition is reduced because of the low fertility. Little bluestem grows on soils that are derived from calcareous and noncalcareous siltstone so carbonate content is not a factor. Wilding (1960) discussed the different soils where little bluestem was abundant, including some which were not well drained.

Sideoats grama grows with the bluestem species and with prairie sandreed on weakly developed soils. It also is abundant where the weakly developed soil has a few inches of dark-colored granular surface soil and blue grama (Bouteloua gracilis), buffalograss (Buchloe dactyloides), and western wheatgrass are important (Fig. 2). Thus, sideoats grama occurs on soils with intermediate characteristics and can compete in pastures with more grass species than most native grasses (Archer and Bunch, 1953, p. 223). The root system which is intermediate in character to those of the 


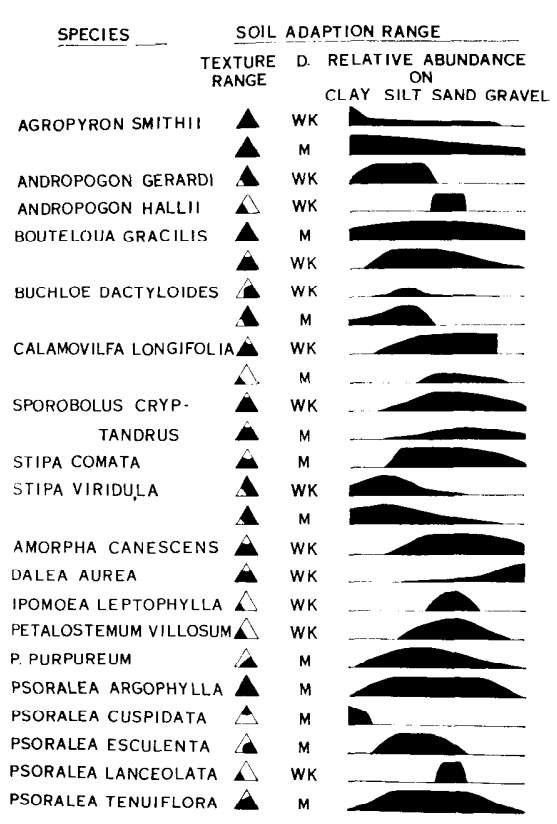

FIc. 3. Relationship of common mixed prairie species to soil texture. The shaded area of the standard soil texture triangle (apex $=100 \%$ clay, lower left $=100 \%$ sand, lower right $=100 \%$ silt) shows the range of soil textures that were found where the species commonly grows when the soil is (Column $D .=$ Development) weak (WK) and moderate or well (M) developed. The linear array of texture, clay through gravel, shows by the height of the shading the relative abundance of a species on soils with the different dominant kinds of soil particles. It cannot be used to compare the abundance of different species on a certain texture.

warm- season tall bunch-grasses and western wheatgrass, has shallow rhizomes with nodal roots that spread down and through the soil.

Needleandthread (Stipa comata) grows on coarse-textured soils and not on fine-textured soils. In contrast, green needlegrass grows on fine-textured soils and not on coarse-textured soils. Both grow on medium and moderately fine textured soils but as the clay content increases, green needlegrass increases relatively to needleandthread. The relationship of these species to texture has been discussed by Archer and Bunch (1953). However, Hoover et al. (1948, p. 698) reported green needlegrass grew best on the sandier soils and Weaver and Albertson (1956, p. 29) con- curred if water is sufficient. Needleandthread docs not grow on clay soils in South Dakota, irrespective of moisture regimes, although green needlegrass grows profusely on the more moist clay soils. Needleandthread has a fine root system (Weaver and Albertson, 1956) that may be damaged more by the desiccation shrinking and cracking in clay soils than the coarse, tough, wiry roots of green needlegrass. In soil derived from moderately fine textured parent materials, horizon textures determine which species is most important (Fig. 2-C). If the A horizon is a silt loam and the $B$ horizon is a clay, needleandthread may grow provided the $\mathbf{B}$ horizon contains many moderately hard siltstone or shale fragments. Needleandthread grows with green needlegrass on soils that have fragmentfree clay B horizons if the A horizon is a silt loam or loam and at least 6 or 8 inches thick. On weakly developed soils, green needlegrass is the sole Stipa sp. if the clay content is more than 40 or 50 percent regardless of the shale fragment content.

Buffalograss grows in association with green needlegrass on many soils. Like green needlegrass, it does not grow well on sandy soils (Weaver and Albertson, 1956; Archer and Bunch, 1953). In Mellette County, buffalograss is found occasionally on soils with sandy surfaces that are underlain by clay but not where the entire profile is sandy. It grows on silty soils where green needlegrass is replaced by needleandthread but not on very weakly devcloped fine-textured clay soils where green needlegrass grows but needleandthread does not. However, buffalograss will grow on these fine-textured clay soils, derived from very weakly bedded, poorly consolidated shales or from clay alluvium, when they develop a granular surface layer and a weak prismatic B horizon. Apparently, buffalograss cannot grow unless the surface and sub-surface layers of a fine-textured clay soil has fairly stable prismatic and blocky structure. The plant will not grow if parallelepipeds are present in the surfacc or within the subsoil to a depth of 10 or 15 inches. Presumably the fine roots of buffalograss are damaged either by constriction or by stretching as the soil dries, shrinks, and cracks (White and Lewis, 1969).

Blue grama, like buffalograss, will not grow on very fine textured soils until the structure becomes fairly stable in the upper part of the soil. However, blue grama does grow on all other soils in Mellette County including the coarsetextured ones where buffalograss does not occur. The sandy soil charcatcristics that limit the one species and not the other are not known. Presumably, the unstable surface-layer structure in very sandy soils may be detrimental to buffalograss.

Western wheatgrass abundance, relative to other species, increases directly with clay content on welldrained soils which lack shale fragments. Weakly developed clay soils with shale fragments have more warm-season tall-grasses than western wheatgrass (Fig. 2-D and E, Pierre-shale-derived soils compared to Tertiary-shale-derived soils). Western wheatgrass is most abundant on soils with B-horizon parallelepiped structure and least important where the B-horizon prisms contain no definite blocky structure. The kind of structure formed is related to the clay content and the shrink-swell capacity of the soil with changes in the moisture content. Apparently, western wheatgrass roots can withstand soilvolume changes better than the roots of species which grow on coarse-textured soils. Western wheatgrass roots grow from rhizome nodes 2 to 4 inches below the surface so the overlying soil structure is not important. In addition, the rhizome-stored carbohydrates maintain the dormant plant during droughts and initiate new growth when the soil is moistened. If a rhizome breaks or is constricted by soil-volume changes, a new plant can arise from nodes to maintain the species. 


\section{Miscellaneous Perennial Grasses}

Sand dropseed (Sporobolus cryptandrus) was common on sandy or silty soils and less common on finetextured soils. In contrast, tall dropseed (Sporobolus asper) was observed mainly on moderately fine and fine-textured soils with at least weak development. Prairie junegrass (Koeleria cristata) and red threeawn (Aristida longiseta) were observed most frequently on silty, loamy, or fine sandy soils with A and B horizons. Stonyhills muhly (Muhlenbergia cuspidata) grew on weakly developed soils formed from any bedrock parent material where erosion was rapid. It usually is associated with little bluestem. Indian ricegrass (Oryzopsis hymenoides) occurred on very weakly developed soils on cliffs in the Badlands where vegetation was sparse. Hairy grama (Bouteloua hirsuta) was found in a very few areas on weakly developed silty or sandy soils. Blowoutgrass (Redfieldia flexuosa) and sand lovegrass (Eragrostis trichodes) were found only in a few sandy formerly cultivated areas where they could have been introduced in domestic seed. These two are common SandHills species where dunes are wind eroded. Their absence in Mellette County may suggest wind blowout activity is recent on formerly stabilized dunes where these species could not grow. Canada wildrye (Elymus canadensis) and virginia wildrye (E. virginicus) were observed rarely on well-drained sloping silty or sandy soils. Switchgrass grew infrequently on well-drained weakly developed soils, possibly where snow accumulated to increase the plant-available soil water. It was common on moist soils.

\section{Forb Species in Relationship to Soil Texture and Development}

Some forbs grow only on welldrained soils with a certain range of textures and are listed in Figure 3 with the general texture range of the soils where they occur frequently. Obviously, most species do grow occasionally in atypical soils where other species are better adapted. Several species seem to be restricted in Mellette County to very weakly developed sandy soils. These are bush morningglory (Ipomoea leptophylla), silky prairieclover (Petalostemum villosum), lemon scurfpea (Psoralea lanceolata), sand sagebrush (Artemisia filifolia), and annual criogonum (Eriogonum annum). Leadplant amorpha (Amorpha canescens) occurs on weakly developed sandy or silty soils. However, the sand may consist of flakes of fissile shale which are exposed by erosion. Dwarfindigo amorpha (Amorpha nana) also occurs most frequently on weakly developed soils but they are derived from weathered clay-rich shale or siltstone. Silktop dalea (Dalea aurea) and plume dalea (Dalea enneandra) are both found on weakly developed soils. Silktop dalea grows on ridges and slopes that have a gravelly subsoil. The gravel may be water deposited or consist of shale or siltstone fragments. Plume dalea grows on finer material where erosion is rapid. White prairieclover (Petalostemum candidium) occurs on very weakly developed soils derived from silty alluvium or partially weathered siltstone or shale. Purple prairieclover (Petalostemum purpureum) grows on more strongly developed soils than white prairieclover. These soils usually have at least a weak $B$ horizon and a darkcolored A horizon. Tall bread scurfpea (Psoralea cuspidata) grows only on weakly to strongly developed soils which are clays or have clay layers in the profile or substratum. It is as diagnostic of clay as lemon scurfpea is of a weakly developed sandy soil. Silverleaf scurfpea $(P$. argophylla) grows readily on most soils except possibly on those which are very gravelly or have a very high clay content. Common breadroot scurfpea $(P$. esculenta) seems to be most prevalent on silty or loamy soils. Slimflower scurfpea (P. tenuiflora) grows on nearly any welldrained soil which has a friable subsoil at a depth of 3 or 4 feet.

Most forbs growing on weakly developed soils are legumes that may have root nodules with symbiotic organisms that fix nitrogen in soils with a low nitrogen content. As soil organic matter accumulates, other forbs and grasses get sufficient nitrogen to compete for the area. Reasons for the non-leguminous forbs growing on soils with a certain texture are not known. Possibly the root systems of some specics are damaged in clay soils while others cannot grow through sandy materials for some unexplained reason.

Selective Effect of Soil Texturc and Development on Plant Species

The selective effect texture has for certain species is evident (Figs. 2 and 3 ). Texture is a factor in air and water movement in the soil, in the amount of water a well-drained soil can retain that is available to plants, in structure formation (White, 1967), and, in some cases, soil fertility, so its effect on plants is difficult to evaluate. A species may grow on a soil because it can utilize some nonsoil resource more efficiently than other species. How èver, this species may grow equally well or better on some other soil where some other species is more efficient. However, a comparison of the successional sequences formed with increasing soil development on different kinds of parent material will eliminate some species from those affected by texture.

Little bluestem, sideoats grama, and western wheatgrass grow on soils of any texture except pure gravel if soil development is correct for the species. Other species grow only on soils of certain textural groups. Some of these species are big bluestem, sand bluestem, needleandthread, green needlegrass, buffalograss, tallbread scurfpea, lemon scurfpea, and silky prairieclover. The logical place to find differences between these species would be in the roots but no consistent difference is apparent. The effect of soil development on certain species supports this idea.

Buffalograss and blue grama will not grow on a very fine-textured soil until the parallelepipeds in the surface layer and subsoil have changed with increasing soil development, respectively, to granules or 
blocks and prisms. These same species do occur on very weakly developed silty soils which have little structure development of any kind. Therefore, stable structure in fine clay soils seems to compensate for the texture as was discussed previously. In other cases, structure development in a soil of a certain textural group does not seem to affect the distribution of the species. Presumably morphological or physiological differences in the roots must permit one species to grow where others cannot.

\section{Literature Cited}

Albertson, F. W. 1937. Ecology of mixed prairie in west central Kansas. Ecol. Monogr. 7:481-457.

Archer, S. G., and C. E. Bunch. 1953. The American grass book. University of Oklahoma, Press, Norman, Oklahoma, $330 \mathrm{p}$.

DIx, R. L. 1958. Some slope-plant relationships in the grasslands of the Little Missouri Badlands of North Dakota. J. Range Manage. 11:88-92.

Fernald, M. L. 1950. Gray's Manual of Botany. Eight Ed., American Book Co., New York.
Hanson; H. C., and W. Wintman. 1938. Characteristics of major grassland types in western North Dakota. Ecol. Monogr. 8:57-114.

Hodges, W. T. 1960. Climate of the States-South Dakota. Climatography of the United States No. 60-39. Weather Bureau, U. S. Dep. of Commerce, Washington, D. C.

Hoover, M. M., M. A. Hein, W. A. Dayton, and C. O. Erlanson. The main grasses for farm and home. (IN) Yearbook of Agriculture. 1948: 639-700.

Hitchcock, A. S., and A. Chase. 1950. Manual of the grasses of the United States. U. S. Dep. Agr. Misc. Pub. No. 200.

Kelsey, H. P., and W. A. Dayton. 1942. Standardized plant names. Ed. 2. J. Horace McFarland Co., Harrisburg, Pa. 675 p.

Klemmedson, J. O. 1970. Needs for soil information in the management of range resources. J. Range Manage. 23:139-143.

Küchler, A. W. 1964. Potential natural vegetation of the conterminous United States. Amer. Geographical Soc. Spec. Pub. 36.

Larson, F., and W. Whitman. 1942. A comparison of used and unused grassland in the Badlands of South Dakota. Ecology 23:438-445.
Lewis, J. K., L. R. Albee, and P. L. Howard. South Dakota Range-Its nature and use. S. Dak. State College, Ext. Circ. 605.

Tolstend, W. L. 1941. Plant communities and secondary succession in southcentral South Dakota. Ecology 22:322-328.

Weaver, J. E. 1958. Summary and interpretation of underground development in natural grassland communities. Ecol. Monogr. 28:55-78.

Weaver, J. E., and F. W. Albertson. 1956. Grasslands of the Great Plains. Johnsen Publishing Company. Lincoln, Nebraska, 395 p.

Weaver, J. E., and R. W. Darland. 1949. Soil-root relationships of certain native grasses in various soil types. Ecol. Monogr. 19:303-338.

White, E. M. 1961. A possible relationship of little bluestem to soils. J. Range Manage. 14:243-247.

White, E. M. 1967. Soil age and texture factors in subsoil structure genesis. Soil Sci. 103:288-298.

White, E. M., and J. K. Lewis. 1969. Ecological effect of a clay soil's structure on some native grass roots. J. Range Manage. 22:401-404.

Wilding, L. P. 1960. The distribution of little bluestem on certain soils in Mellette County, South Dakota. S. Dak. Acad. Sci. Proc. (1959) 38:74-78.

\section{COMMONWEALTH AGRICULTURAL BUREAUX}

\section{Publishers of: HERBAGE ABSTRACTS, FIELD CROP ABSTRACTS}

\section{AUTOMATION OF CAB SERVICES}

The Commonwealth Agricultural Bureaux are introducing computer techniques for the provision of specialist scientific information services for agricultural research workers. The new system will facilitate:

(a) speedier journal production and earlier notice of papers;

(b) the inclusion of improved indexes in each journal issue;

(c) the search of the whole CAB data base to provide special outputs on selected topics, current awareness, personal and group services, annotated bibliographies, etc.;

(d) the interchange of information with other major information services in this field;

(e) the supply of magnetic tapes.

Some automated journal production will start in 1972 and further details will be announced in due course. Any enquiries should be addressed to:

Systems Manager, Commonwealth Agricultural Bureaux, Farnham House, Farnham Royal, Slough SL2 3BN, ENGland. 